\title{
Pengaruh Intrusi Basalt terhadap Karakteristik dan Kualitas Batugamping pada Quarry Bukit Karang Putih, Indarung, Padang, Sumatra Barat
}

\author{
Jenian Marin $^{1 *}$, Tri Winarno ${ }^{1}$, Ulfah Rahmadani ${ }^{1}$ \\ ${ }^{1}$ Departemen Teknik Geologi, Universitas Diponegoro
}

\begin{abstract}
Abstrak
Quarry Bukit Karang Putih, Indarung milik PT Semen Padang adalah komplek batugamping berumur Jura yang terintrusi oleh basalt. Sebagai bahan baku utama industri semen, batugamping di lokasi penelitian harus memenuhi standar kualitas yang ditetapkan. Penelitian ini bertujuan untuk mengetahui karakteristik batugamping dari quarry Bukit Karang Putih dari aspek mineralogi dan kimianya, dikaitkan dengan pengaruh keberadaan intrusi. Metode analisis yang digunakan adalah petrografi dan XRF untuk mengetahui karakteristik mineralogi dan geokimia batuan dari sampel batugamping dan intrusi basalt, kemudian dikorelasikan dikorelasikan dengan data pengeboran. Litologi daerah penelitian berupa batugamping kristalin, tuf terubahkan, serta intrusi basalt. Batugamping memiliki karakteristik warna putih, struktur masif, tekstur kristalin. Batuan tersusun oleh kalsit dengan bentuk kristal equant, batas sutured, dengan tekstur lamellar twinning yang menunjukkan adanya diagenesis lanjut akibat tekanan dan metamorfisme. Batugamping terintrusi retas basalt porfir yang berkomposisi plagioklas dan piroksen di antara gelas vulkanik. Analisis XRF menunjukkan bahwa kadar $\mathrm{CaO}$ batugamping menurun mendekati tubuh intrusi, sedangkan $\mathrm{SiO}_{2}$ akan bertambah apabila semakin dekat dengan tubuh intrusi. Pengurangan kadar $\mathrm{CaO}$ tidak terlalu signifikan sehingga tetap memenuhi standar PT Semen Padang. Sedangkan penambahan kandungan $\mathrm{SiO}_{2}$ dari intrusi basalt membuat kualitas batugamping semakin baik untuk dijadikan bahan baku semen.
\end{abstract}

Kata kunci: batugamping, industri semen, intrusi basalt, Indarung

\begin{abstract}
Bukit Karang Putih quarry, Indarung owned by PT Semen Padang is a Jurassic limestone complex intruded by basalt. As the main raw material for the cement industry, limestone at the study site must meet the specified quality standards. The study aims to determine the characteristics of limestone from the Bukit Karang Putih quarry from its mineralogical and chemical aspects, related to the influence of the presence of intrusion. This research method is a field survey to map lithology and collect samples. Limestone and intrusion samples were analyzed by petrography and XRF geochemistry to determine their characteristics and quality, correlated with lithological drilling data. The lithology of the research area is crystalline limestone, altered tuff, and basalt intrusion. Limestone has the characteristics of white color, massive structure, crystalline texture. The rocks are composed of calcite in the form of equant crystals, sutured boundaries, with the texture of lamellar twinning which indicates the presence of advanced diagenesis due to pressure and metamorphism. Basaltic dyke which intruded limestone, composed of plagioclase and pyroxene between volcanic glass groundmass. XRF analysis shows that the limestone $\mathrm{CaO}$ levels decrease approaching the intrusion body. $\mathrm{SiO}_{2}$ levels increase nearer to the intrusion. However, the reduction in CaO levels is not too significant so that it still meets the standards of PT Semen Padang. While the addition of $\mathrm{SiO}_{2}$ content from intrusion makes the quality of limestone better raw material for cement.
\end{abstract}

Keywords: limestone, cement industry, basalt intrusion, Indarung

\section{PENDAHULUAN}

Indarung memiliki kondisi geologi yang kompleks yaitu batuan sedimen Mesozoik yang ditindih secara tidak selaras oleh batuan vulkanik Neogen (Yancey dan Alif, 1977 dalam Barber, 2000; McCarthy dkk, 2001).

*) Korespondensi: jenianmarin@gmail.com 
Barber (2000) menyatakan bahwa kompleks ini merupakan bagian dari Kelompok Woyla berumur Jura-Kapur di Sumatra. Kumpulan dari batuan sedimen hasil pengendapan cekungan Mesozoik, batuan dari busur vulkanik, hingga batuan intrusi menunjukkan batas kontinen dengan Sundaland.

Quarry Bukit Karang Putih adalah galian batugamping yang merupakan bagian dari kompleks Pabrik Indarung, milik PT. Semen Padang, sekitar $10 \mathrm{~km}$ dari Kota Padang, Sumatra Barat. Selain batugamping, dibutuhkan bahan baku lain yaitu silika dan tanah liat untuk memenuhi standar kualitas semen yang telah ditetapkan. Keberagaman batuan di Indarung menjadi kondisi geologi yang ideal bagi produksi semen. Selain batugamping, batuan silika dari Bukit Ngalau juga merupakan bahan utama dalam proses produksi. Batugamping di Bukit Karang Putih berasosiasi pula dengan intrusi batuan beku yang diperkirakan mempengaruhi karakteristik dan kualitasnya. Penelitian ini bertujuan untuk mengetahui karakteristik batugamping dari quarry Bukit Karang Putih dari aspek mineralogi dan kimia kualitasnya, dikaitkan dengan pengaruh keberadaan intrusi di dalamnya.

\section{GEOLOGI REGIONAL}

Lapangan Bukit Karang Putih Indarung memiliki variasi batuan yang beragam. Menurut Kastowo (1973), litologi daerah penelitian terdiri dari terdiri dari lima formasi batuan (Gambar 1).

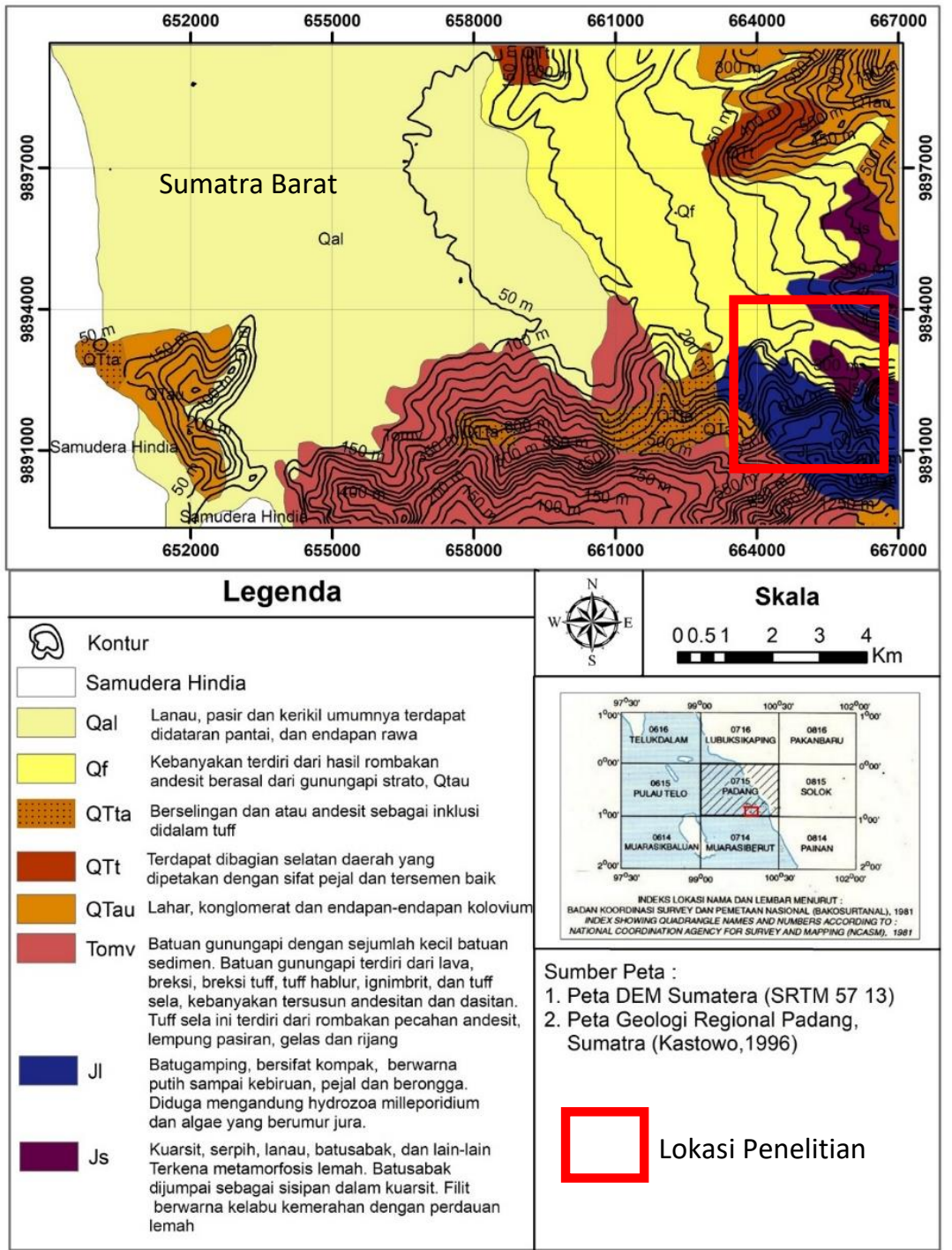

Gambar 1. Peta geologi regional daerah penelitian (modifikasi dari Kastowo, 1973) 


\section{Batugamping Jura (JI)}

Terdiri dari batugamping, kompak, berwarna putih hingga abu-abu kebiruan, padat dan berongga. Diduga mengandung Hydrozoa milleporidium dan algae yang berumur Jura. Dapat dikorelasikan dengan Anggota Batugamping Formasi Siguntur (Jsl) di Lembar Painan dan bagian timur laut Muarasiberut.

\section{Sedimen Jura (Js)}

Terdiri dari kuarsit, batuserpih, lanau, batusabak, mengalami metamorfisme lemah. Kuarsit bersifat kompak, berwarna abu-abu kehijauan, sedikit terubah, setempat menyerupai rijang. Batuserpih, memiliki tekstur filitik, berwarna biru tua. Batulanau, bersifat kompak, berwarna kebiruan sampai kehijauan. Batusabak dijumpai sebagai sisipan dalam kuarsit, tekstur filitik berwarna abu-abu kemerahan.

\section{Tuf Kristal yang Telah Mengeras (Tomv)}

Batuan formasi ini berumur Jura Akhir hingga Tersier Awal (McCarthy dkk, 2001) dengan tekstur kristalin dan padat serta sangat keras. Berwarna merah kecoklatan hingga putih, merupakan hasil ubahan akibat kontak dengan intrusi. Salah satu batuan dari formasi ini adalah Golok Tuff yang memiliki kontak tidak selaras dengan batugamping Lubuk Peraku.

\section{Intrusi Basalt (Tmb)}

Formasi ini terdiri dari intrusi batuan yang berkomposisi basaltik. Intrusi ini menerobos batuan meta sedimen (batuan sedimen Jura dan batugamping Jura). Formasi ini ditutupi oleh batuan sedimen Kuarter sehingga diinterpretasi umur formasi ini adalah Tersier.

\section{Kipas Aluvial (Qf)}

Formasi ini didominasi oleh hasil rombakan andesit yang berasal dari gunungapi strato. Permukaannya ditutupi oleh bongkahbongkah andesit. Kipas aluvial yang terdapat pada lereng-lereng gunungapi Kuarter dipetakan sebagai hasil dari gunungapi tersebut.

\section{KUALITAS SEMEN}

Industri semen berkaitan erat dengan batugamping sebagai bahan bakunya. Tidak semua batugamping memenuhi standar untuk dijadikan sebagai bahan baku semen. Banyak pertimbangan yang dilihat dari segi kualitas maupun kuantitas. Setiap pabrik semen biasanya memiliki standar kimia yang berbeda-beda tergantung kondisi lapangan dan jenis semen yang akan dihasilkan. PT Semen Padang memiliki standar kimia sendiri dalam penentuan bahan baku semen sebagai berikut (Tabel 1).

Tabel 1. Kadar kimia batugamping yang memenuhi standar bahan baku pada PT Semen Padang (Prabowo, 2007)

\begin{tabular}{cc}
\hline Senyawa & Kadar $(\%)$ \\
\hline $\mathrm{CaO}$ & $48-56$ \\
$\mathrm{SiO}_{2}$ & $0,76-5$ \\
$\mathrm{Al}_{2} \mathrm{O}_{3}$ & $0,71-2$ \\
$\mathrm{Fe}_{2} \mathrm{O}_{3}$ & $0,36-1,47$ \\
$\mathrm{MgO}$ & $0,3-1,48$ \\
$\mathrm{H}_{2} \mathrm{O}$ & $0-6$ \\
\hline
\end{tabular}

\section{METODOLOGI}

Informasi mengenai kondisi geologi daerah penelitian dari studi terdahulu dikumpulkan untuk memperoleh gambaran umum sebelum melakukan survei lapangan. Observasi geologi dilakukan untuk mengetahui karakteristik dan persebaran litologi di lapangan. Sebanyak 4 sampel terpilih dianalisis petrografi untuk mengetahui komposisi mineralogi dan tekstur batuan. Data pengeboran sebanyak 5 titik oleh PT. Semen Padang digunakan untuk menginterpretasi kondisi geologi bawah permukaan.

Untuk mengetahui komposisi kimia yang berkaitan dengan kualitas, dilakukan analisis XRF (X-Ray Fluorescence) terhadap komponen $\mathrm{CaO}, \mathrm{MgO}, \mathrm{Al}_{2} \mathrm{O}_{3}$, dan $\mathrm{SiO}_{2}$. Analisis dilakukan pada 20 sampel, singkapan di permukaan dengan teknik pengambilan berjarak sistematis dari tubuh intrusi basalt. Korelasi litologi permukaan dan pengeboran dengan komposisi kimia dilakukan untuk mengetahui adanya pengaruh intrusi basalt terhadap karakteristik dan kualitas kimia batugamping daerah penelitian.

\section{HASIL PENELITIAN \\ Litologi Daerah Penelitian}

Pemetaan dilakukan pada sebagian quarry Bukit Karang Putih di front III, V, dan VIB dengan cakupan area $700 \mathrm{~m}$ x $800 \mathrm{~m}$. Hasil 
pemetaan geologi didapatkan empat satuan litologi (Gambar 3), sebagai berikut:

\section{Batugamping Kristalin}

Singkapan batuan memiliki tingkat pelapukan rendah hingga sedang, dengan warna segar putih, struktur masif tanpa adanya perlapisan batuan. Tekstur batugamping yang tampak adalah kristalin, dengan ukuran kristal kalsit yang kasar, warna jernih-putih, bentuk equant, dan berkilap kaca. Pengamatan pada sayatan tipis batuan menunjukkan komposisi dominan kristal kalsit dengan kenampakan adanya lamellar twinning (Gambar 2). Tekstur ini merupakan salah satu tekstur deformasi yang terbentuk setelah diagenesis karbonat, batuan mengalami tekanan yang tinggi akibat gaya endogen. Batugamping kristalin yang dekat dengan tubuh intrusi tidak menunjukkan kenampakan fisik yang berbeda jauh satu sama lain jika dibandingkan dengan batugamping kristalin yang lebih jauh dari tubuh intrusi.

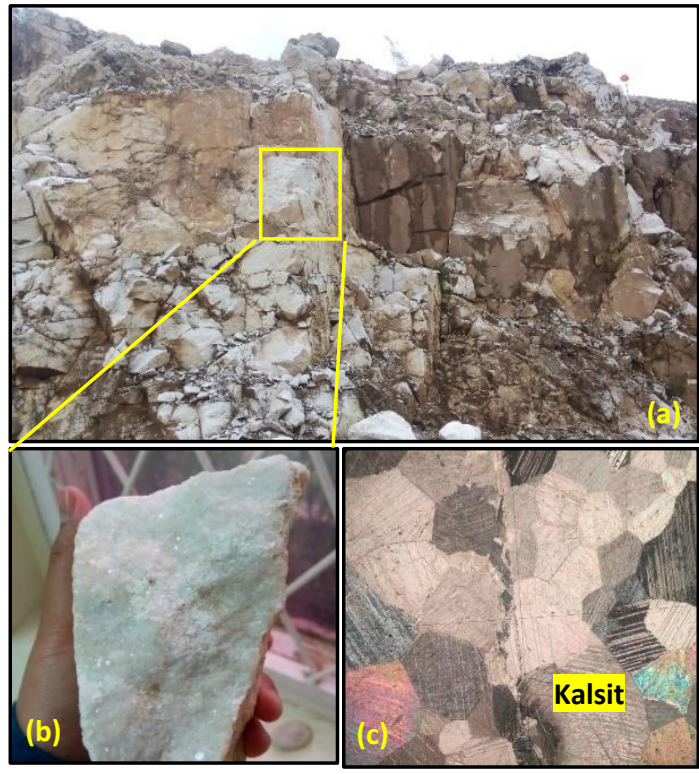

Gambar 2. (a) Kenampakan lereng galian batugamping di Bukit Karang Putih, (b) kristal kalsit penyusun batugamping kristalin, (c) tekstur lamellar twinning pada kalsit

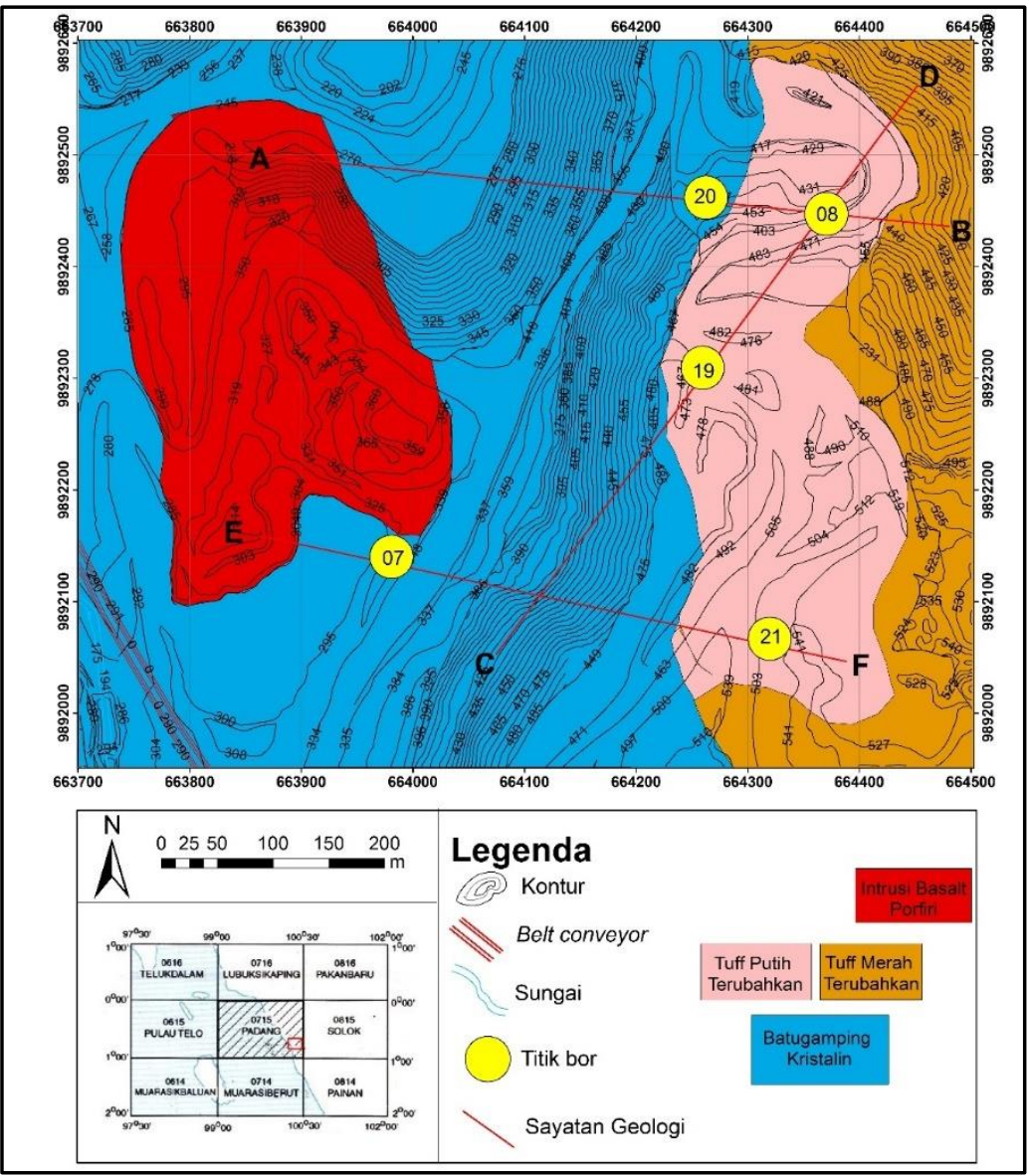

Gambar 3. Peta geologi daerah penelitian, dengan persebaran titik bor dan lokasi pengambilan sampel geokimia 
Tuf Putih Terubahkan

Singkapan tuf putih terubahkan memiliki tingkat pelapukan yang rendah hingga sedang. Batuan memiliki kenampakan warna abu-abu cerah hingga putih, ukuran butir halus, sangat keras, serta terkekarkan intensif. Berdasarkan pengamatan petrografi, batuan tersusun oleh dominan gelas vulkanik dan kuarsa. Rekahan terisi oleh mineral kuarsa berukuran halus (Gambar 4a, b). Keberadaan kekar gerus dan tarik yang intensif, urat kuarsa, dan sifat yang keras ini disebabkan adanya proses ubahan yaitu silisifikasi. Berdasarkan analisis geokimia, kandungan silika batuan mencapai 80-90\%. McCarthy dkk (2001) menyebutkan bahwa tuf ini berumur Jura, dan terubah akibat asosiasi dengan batuan intrusi.

\section{Tuf Merah Terubahkan}

Tuf merah terubahkan memiliki tingkat pelapukan yang sedang hingga tinggi. Karakteristik fisiknya berwarna merah kecoklatan, ukuran halus, keras, terkekarkan intensif. Litologi ini dibedakan dengan tuf putih terubahkan karena karakteristik dan komposisi yang berbeda, meskipun diperkirakan formasi batuan berumur sama. Komposisi yang terlihat pada sayatan tipis menunjukkan batuan tersusun oleh gelas vulkanik, mineral opak, dan oksida besi (Gambar 4c, d). Mineral oksida besi tampak berbentuk dendritik dan berwarna coklat kemerahan. Kekar juga terisi oleh mineral ini. Analisis geokimia menunjukkan silika lebih rendah dari tuf putih terubahkan, yaitu 60$80 \%$.

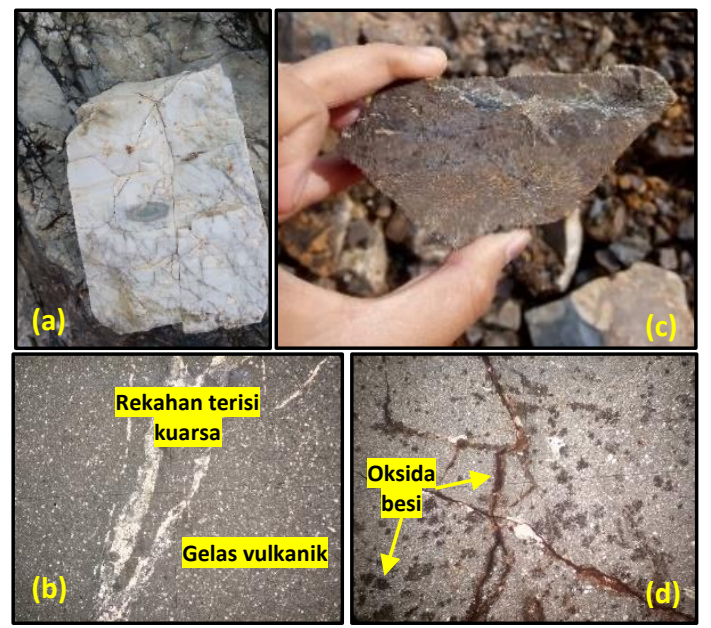

Gambar 4. (a, b) Tuf putih terubahkan dengan komposisi gelas vulkanik dan rekahan terisi kuarsa, (c, d) Tuf merah terubahkan dengan oksida besi

\section{Intrusi Basalt}

Intrusi basalt terdapat di sebelah barat daerah penelitian, tepat pada area produksi. Singkapan berwarna abu-abu gelap, dengan tingkat pelapukan rendah-sedang, struktur masif. Karakteristik petrologi memiliki tekstur porfiritik yang terlihat dari fenokris plagioklas dan piroksen pada massa dasar gelas vulkanik. Plagioklas tipe bitownit (An. 70-90) mendominasi batuan intrusi, sehingga intrusi diklasifikasikan sebagai basalt. Kontak di lapangan menunjukkan bahwa tubuh intrusi basalt ini membentuk retas/dyke yang memotong tubuh batugamping (Gambar 5).

\section{Penampang Bawah Permukaan}

Berdasarkan litologi dari data pengeboran, dapat dikorelasikan kondisi litologi bawah permukaan. Data pengeboran sebanyak 5 titik menunjukkan adanya ketebalan batugamping yang cukup signifikan (Gambar 6). KRP 20 menunjukkan litologi batugamping dengan tebal mencapai $181 \mathrm{~m}$. KRP 08 dan 21 menunjukkan bahwa tuf terubahkan setebal 5$10 \mathrm{~m}$ berada di atas lapisan batugamping yang tebal. Selain keberadaan tubuh intrusi basalt di

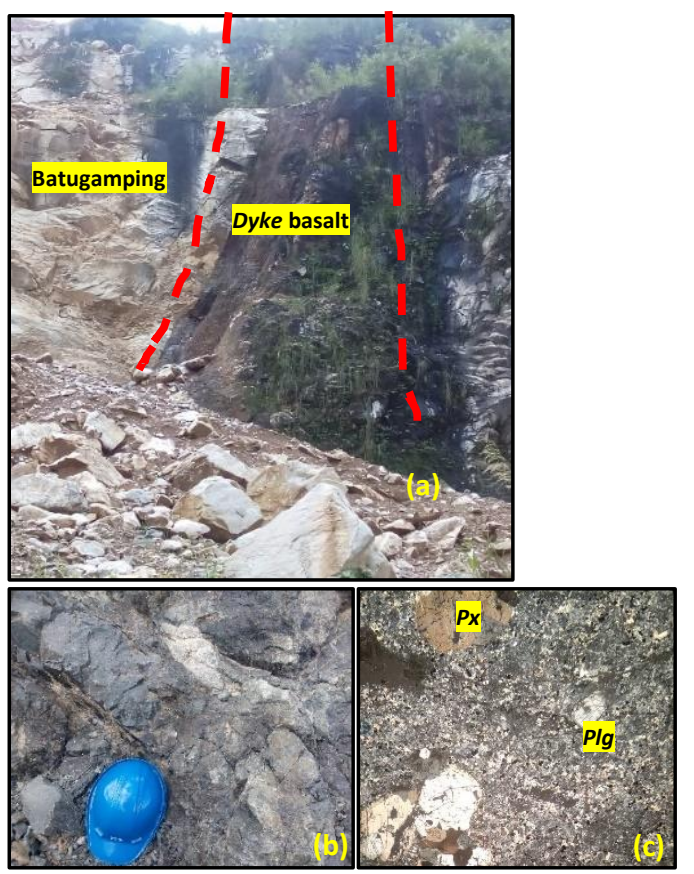

Gambar 5. (a) Basalt mengintrusi tubuh batugamping, (b, c) Kenampakan basalt dan sayatan tipisnya menunjukkan plagioklas (Plg) dan piroksen $(\mathrm{Px})$ pada massa dasar halus. 
permukaan, juga diketahui terdapat intrusi basalt yang menyisip di antara lapisan tuf dan batugamping pada KRP 08 dan 07.

Berdasarkan pemetaan litologi dan korelasi log bor batuan di atas, maka dapat diinterpretasikan bahwa tuf terubahkan memiliki ketebalan beberapa meter di atas batugamping di bawahnya. Oleh karena itu dalam perencanaan penambangan, batugamping yang berada di bawah tuf terubahkan dari segi kedudukan batuan memiliki potensi dan prospek untuk dilakukan penambangan sebagai salah satu bahan baku semen di PT Semen Padang. Namun, untuk mengetahui kualitas dan kandungan kimia batugamping apakah sesuai dengan standar kimia dalam bahan baku semen diperlukan analisis geokimia dengan metode XRF yang akan dijelaskan selanjutnya.

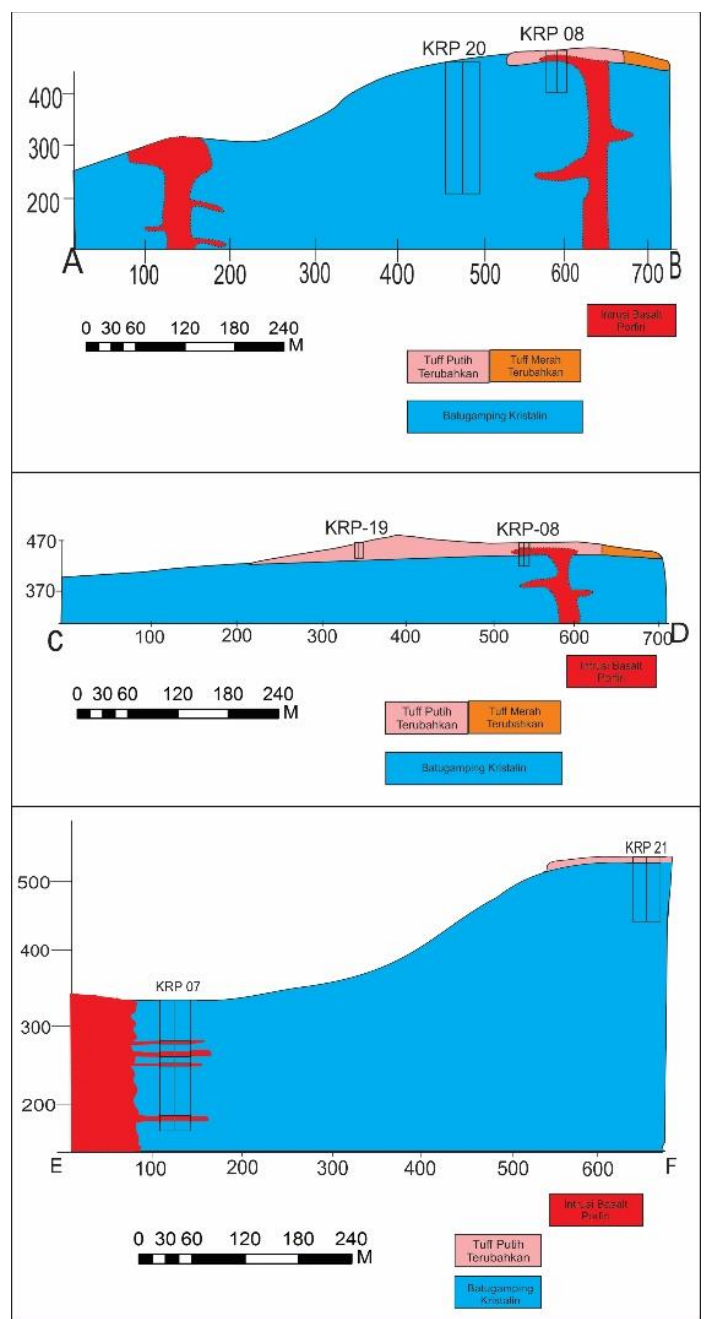

Gambar 6. Penampang litologi bawah permukaan berdasarkan data pemboran

\section{Analisis Geokimia}

Tujuan utama dilakukannya analisis geokimia dengan metode XRF adalah untuk mengetahui komponen kimia yang menjadi parameter kualitas batugamping yaitu $\mathrm{CaO}, \mathrm{SiO}_{2}, \mathrm{Al}_{2} \mathrm{O}_{3}$, dan $\mathrm{MgO}$. Untuk mengetahui adanya pengaruh intrusi basalt terhadap komposisi kimia, sampel yang diambil pada 4 lintasan dengan jarak interval sistematis tiap $10 \mathrm{~m}$ dari kontak intrusi-batugamping.

Hasil analisis geokimia (Tabel 1) menunjukkan bahwa terdapat perubahan komposisi kimia dengan jarak terhadap intrusi basalt. Secara kimia sendiri, basalt yang dekat dengan kontak batugamping berkomposisi $\mathrm{SiO}_{2}$ 57,60\%; $\mathrm{Al}_{2} \mathrm{O}_{3}$ 13,00\%; $\mathrm{CaO} 12,10 \%$; dan $\mathrm{MgO} 3 \%$. Komponen $\mathrm{CaO}$ relatif tinggi dibanding rata-rata basalt pada umumnya, karena sampel diambil pada sekitar kontak intrusi. Secara umum, terdapat perbedaan kimia yang terlihat pada seluruh sampel batugamping kaitannya dengan jarak terhadap intrusi.

$\mathrm{SiO}_{2}$

Oksida ini merupakan komponen yang paling melimpah pada batuan beku, dalam hal ini intrusi basalt di daerah penelitian. Sampel batugamping yang diambil pada jarak terdekat dengan intrusi, yaitu $10 \mathrm{~m}$ memiliki persentase $\mathrm{SiO}_{2}$ rata-rata sebesar 2,53\%. Semakin jauh dari intrusi, terdapat kecenderungan penurunan yang signifikan dari komponen $\mathrm{SiO}_{2}$ pada batugamping, yaitu sampel terjauh $50 \mathrm{~m}$ dari intrusi memiliki ratarata $\mathrm{SiO}_{2} 0,35 \%$.

$\mathrm{Al}_{2} \mathrm{O}_{3}$

$\mathrm{Al}_{2} \mathrm{O}_{3}$ secara umum rendah pada batugamping, karena biasanya berasal dari mineral/material batuan beku. Hasil analisis sampel batugamping yang diambil pada jarak terdekat dengan intrusi, yaitu $10 \mathrm{~m}$ memiliki persentase $\mathrm{Al}_{2} \mathrm{O}_{3}$ rata-rata sebesar $0,67 \%$. Semakin jauh dari intrusi, terdapat kecenderungan penurunan komponen $\mathrm{Al}_{2} \mathrm{O}_{3}$ pada batugamping, yaitu sampel terjauh $50 \mathrm{~m}$ dari intrusi memiliki rata-rata $\mathrm{Al}_{2} \mathrm{O}_{3} 0,07 \%$.

$\mathrm{CaO}$

Sebagai komponen utama dalam batugamping, $\mathrm{CaO}$ berasal dari mineral kalsit $\left(\mathrm{CaCO}_{3}\right)$. Berdasarkan analisis kimia, sampel 
Tabel 1. Hasil analisis geokimia XRF sampel batugamping dan basalt tiap interval $10 \mathrm{~m}$ dari intrusi

\begin{tabular}{|c|c|c|c|c|c|c|}
\hline \multirow{2}{*}{$\begin{array}{c}\text { Kode } \\
\text { Sampel }\end{array}$} & \multirow{2}{*}{ Sampel Batuan } & \multirow{2}{*}{$\begin{array}{l}\text { Jarak dari intrusi } \\
(\mathrm{m})\end{array}$} & \multicolumn{4}{|c|}{ Komposisi Kimia (\%) } \\
\hline & & & $\mathrm{SiO}_{2}$ & $\mathrm{Al}_{2} \mathrm{O}_{3}$ & $\mathrm{CaO}$ & $\mathrm{MgO}$ \\
\hline A0 & Basalt & 0 & 53,84 & 16,82 & 22,94 & 1,7 \\
\hline A1 & Batugamping & 10 & 3,49 & 1,22 & 51,42 & 0,56 \\
\hline $\mathrm{A} 2$ & Batugamping & 20 & 0,21 & 0,13 & 54,97 & 0,41 \\
\hline A3 & Batugamping & 30 & 0,14 & 0,12 & 55,09 & 0,38 \\
\hline A4 & Batugamping & 40 & 0,72 & 0,36 & 56,91 & 0,49 \\
\hline A5 & Batugamping & 50 & 0,43 & 0,15 & 58,7 & 0,49 \\
\hline B0 & Basalt & 0 & 61,49 & 15,17 & 18,53 & 3,41 \\
\hline B1 & Batugamping & 10 & 0,98 & 0,55 & 54,35 & 0,37 \\
\hline B2 & Batugamping & 20 & 0,39 & 0,15 & 54,93 & 0,43 \\
\hline B3 & Batugamping & 30 & 0,21 & 0,13 & 54,97 & 0,41 \\
\hline B4 & Batugamping & 40 & 0,14 & 0,12 & 55,09 & 0,38 \\
\hline B5 & Batugamping & 50 & 0,12 & 0,01 & 56,25 & 0,38 \\
\hline $\mathrm{C} 0$ & Basalt & 0 & 57,41 & 8,17 & 1,67 & 3,37 \\
\hline $\mathrm{C} 1$ & Batugamping & 10 & 1,79 & 0,17 & 54,27 & 0,35 \\
\hline $\mathrm{C} 2$ & Batugamping & 20 & 1,79 & 0,17 & 54,27 & 0,27 \\
\hline $\mathrm{C} 3$ & Batugamping & 30 & 1,79 & 0,17 & 54,27 & 0,25 \\
\hline $\mathrm{C} 4$ & Batugamping & 40 & 0,51 & 0,04 & 54,97 & 0,17 \\
\hline $\mathrm{C} 5$ & Batugamping & 50 & 0,51 & 0,04 & 54,97 & 0,17 \\
\hline D0 & Basalt & 0 & 57,64 & 11,82 & 5,27 & 3,51 \\
\hline D1 & Batugamping & 10 & 3,84 & 0,75 & 51,35 & 0,43 \\
\hline D2 & Batugamping & 20 & 1,06 & 0,37 & 53,36 & 0,45 \\
\hline D3 & Batugamping & 30 & 0,57 & 0,29 & 53,77 & 0,7 \\
\hline D4 & Batugamping & 40 & 0,27 & 0,32 & 54,02 & 0,52 \\
\hline D5 & Batugamping & 50 & 0,32 & 0,08 & 54,12 & 0,48 \\
\hline Rata-rata & Basalt & 0 & 57,60 & 13,00 & 12,10 & 3,00 \\
\hline Rata-rata & Batugamping & 10 & 2,53 & 0,67 & 52,85 & 0,43 \\
\hline Rata-rata & Batugamping & 20 & 0,86 & 0,21 & 54,38 & 0,39 \\
\hline Rata-rata & Batugamping & 30 & 0,68 & 0,18 & 54,53 & 0,44 \\
\hline Rata-rata & Batugamping & 40 & 0,41 & 0,21 & 55,25 & 0,39 \\
\hline Rata-rata & Batugamping & 50 & 0,35 & 0,07 & 56,01 & 0,38 \\
\hline
\end{tabular}

yang dekat dengan intrusi memiliki $\mathrm{CaO}$ yang lebih rendah dibandingkan sampel yang jauh dengan intrusi. Perubahan ini cukup signifikan, dapat dilihat dari sampel terdekat berjarak $10 \mathrm{~m}$ dari intrusi yang memiliki kadar $\mathrm{CaO}$ sebesar $52,85 \%$. Semakin jauh dari intrusi, $\mathrm{CaO}$ semakin naik secara signifikan hingga $56,01 \%$ pada sampel berjarak $50 \mathrm{~m}$.

\section{$\mathrm{MgO}$}

Oksida ini dapat berasal dari material batuan beku maupun batuan sedimen, misalnya dolomit $\left(\mathrm{CaMg}(\mathrm{CO} 3)_{2}\right)$. Pada sampel yang dianalisis, $\mathrm{MgO}$ berkisar 0,38\% - 0,44\%. Perubahan ini tidak signifikan dan tidak tampak kecenderungan yang jelas apakah mengalami kenaikan atau penurunan seiring pengaruh intrusi basalt.

\section{PEMBAHASAN}

Quarry batugamping Bukit Karang Putih, Indarung, PT Semen Padang memiliki kompleksitas geologi yang terdiri dari berbagai macam batuan yaitu intrusi batuan beku (basalt, granit, andesit), batuan sedimen (rijang, batupasir), batuan metasedimen (batugamping kristalin), batuan vulkanik terubahkan (tuf terubahkan). Batuan tertua di daerah penelitian adalah batugamping kristalin yang termasuk ke dalam Formasi Batugamping Jura (Jl) yang bersifat kompak dan pejal (Kastowo, 1973). Menurut McCarthy dkk (2001), batugamping di quarry Bukit Karang Putih sebagian telah termetamorfkan menjadi marmer dengan derajat beragam. Seluruh material karbonat telah terekristalisasi dengan kompak.

Hal ini terlihat pada kenampakan singkapan batuan di Bukit Karang Putih, dimana tidak terdapat indikasi perlapisan. Batugamping memiliki kenampakan megaskopis yang terdiri dari butiran kristalkristal yang disebut juga dengan sugary limestone. Berdasarkan singkapan batuan, tingkat pelapukan cenderung rendah. Tidak terlihat fosil organisme seperti foram, alga 
Tabel 2. Kadar kimia batugamping di daerah penelitian. Standar PT. Semen Padang dari Prabowo (2007)

\begin{tabular}{ccc}
\hline Senyawa & $\begin{array}{c}\text { Standar PT } \\
\text { Semen } \\
\text { Padang (\%) }\end{array}$ & $\begin{array}{c}\text { Hasil analisis } \\
(\%)\end{array}$ \\
\hline $\mathrm{CaO}$ & $48-56$ & $52,85-56,01$ \\
$\mathrm{SiO}_{2}$ & $0,76-5$ & $0,35-2,53$ \\
$\mathrm{Al}_{2} \mathrm{O}_{3}$ & $0,71-2$ & $0,07-0,67$ \\
$\mathrm{Fe}_{2} \mathrm{O}_{3}$ & $0,36-1,47$ & No data \\
$\mathrm{MgO}$ & $0,3-1,48$ & $0,38-0,44$ \\
\hline
\end{tabular}

ataupun terumbu pada batuan secara petrologi. Butiran kristal dapat terlihat jelas pada kenampakan megaskopis diinterpretasikan akibat kontak dengan intrusi basalt yang menyebabkan terjadinya rekristalisasi pada batuan sehingga kristal tumbuh dan berkembang.

Pengamatan petrografi menunjukkan minimnya tekstur sisa batuan sedimen. Penempatan intrusi basalt yang suhunya tinggi turut mengubah tekstur mineral kalsit dengan ukuran kristal kasar. Hal ini diinterpretasikan dari adanya kontak batugamping dengan intrusi basalt yang menyebabkan batuan yang sudah mengalami rekristalisasi, kemudian akibat suhu yang tinggi membuat mineralmineral pada batuan tumbuh kasar (1-3 mm) dengan bentuk equant. Proses deformasi tektonik juga membentuk adanya tekstur lamellar twinning yang jelas. Menurut Burkhard (1993), kembaran lamelar ini dapat terbentuk pada berbagai rezim tektonik dengan suhu yang juga mempengaruhi bentuknya. Selain itu menurut Passchier dan Trow (2005) dalam Fossen (2010), tektonisme juga berpengaruh terhadap pembentukan lamellar twinning ini. Adanya proses dislokasi yang berlangsung pada struktur dalam kristal kalsit disebabkan oleh pengaruh kompresi atau tekanan yang tinggi. Batuan ini diinterpretasikan pula telah mengalami proses neomorfisme. Adanya lamellar twinning juga sebagai penciri bahwa batuan telah mengalami fase metamorfisme (Craig dan Vaughan, 1981).

Batugamping berumur Jura ini terintrusi oleh batuan beku berupa basalt dari Formasi Intrusi Basalt (Tmb). Keberadaan intrusi ini, selain mempengaruhi kenampakan fisik dan tekstur batuan juga mempengaruhi geokimia dan kualitasnya. Intrusi basalt meningkatkan oksida $\mathrm{SiO}_{2}$ secara signifikan di batugamping yang kontak dengan intrusi hingga 2-3\%. Sedangkan komponen utama batugamping yaitu $\mathrm{CaO}$ juga mengalami perubahan akibat pengaruh intrusi, yaitu semakin dekat dengan intrusi maka kadarnya akan semakin berkurang. Percampuran dan pertukaran unsur akibat aktivitas dan fluida magmatik sangat umum dijumpai. Pada beberapa kasus, jika fluida magmatik cukup besar, perubahan mineralogi juga akan terjadi. Pada daerah penelitian, mineralogi batugamping tidak banyak berubah.

Kualitas batugamping di daerah penelitian memenuhi syarat dan standar untuk pemanfaatan bahan baku semen (Tabel 2). Batugamping pada daerah yang dekat dengan intrusi basalt masih memiliki kadar $\mathrm{CaO}$ yang berada dalam standar kualitas. Sedangkan peningkatan silika juga menjadi nilai tambah, karena diperlukan dalam campuran bahan semen. Sehingga, dengan keberadaan intrusi basalt ini, kualitas batugamping di daerah penelitian semakin baik. Bagi batugamping yang kandungan silikanya masih di bawah standar, dapat diatasi dengan mencampur batuan kaya silika di daerah penelitian, yaitu tuf terubahkan yang memiliki kandungan silika 60-90\%. Pada Pabrik Indarung sendiri, batugamping dari Bukit Karang Putih bukan satu-satunya bahan baku semen. Namun, perlu ditambahkan silika yang diambil dari Bukit Ngalau di dekat daerah penelitian.

\section{KESIMPULAN}

Batugamping dari quarry Bukit Karang Putih, Indarung memiliki karakteristik yang dipengaruhi keberadaan intrusi basalt sebagai berikut:

1. Batugamping telah terekristalisasi sehingga disebut batugamping kristalin yang masif dan tidak tampak struktur sedimen. Rekristalisasi menjadikan kalsit berukuran kasar, ekuidimensional, dan tampak lamellar twinning. Selain dari pengaruh intrusi, deformasi dan rezim tektonik juga mempengaruhi karakteristik batugamping berumur Jura ini.

2. Batugamping yang mendekati kontak intrusi memiliki kenaikan kandungan $\mathrm{SiO}_{2}$ dan $\mathrm{Al}_{2} \mathrm{O}_{3}$. Sedangkan $\mathrm{CaO}$ cenderung 
menurun seiring berkurangnya jarak dengan intrusi. Namun demikian, kandungan unsur-unsur tersebut masih menunjukkan kelayakan sebagai bahan baku semen menurut standar PT. Semen Padang.

\section{UCAPAN TERIMA KASIH}

Penulis mengucapkan terima kasih kepada PT. Semen Padang yang telah memfasilitasi pengambilan data di lapangan serta data-data lain yang mendukung penelitian ini.

\section{DAFTAR PUSTAKA}

Barber, A.J., 2000, The origin of the Woyla Terranes in Sumatra and the Late Mesozoic evolution of the Sundaland margin. Journal of Asian Earth Sciences, 18, hal. 713-738.

Burkhard, M., 1993. Calcite twins, their geometry, appearance and significance as stress-strain markers and indicators of tectonic regime: a review. Journal of Structural Geology, 15, hal. 351-368.
Craig J.R. dan Vaughan, 1981. Ore Microscopy and Ore Petrography. John Wiley and Sons: USA.

Fossen, H., 2010. Structural Geology. Published in the United States of America. Cambridge University Press: New York.

Kastowo, K., 1973. Peta Geologi Lembar Padang, Sumatera, Skala 1:250.000. Publikasi Pusat Penelitian dan Pengembangan Geologi.

McCarthy, A., Jasin, B. dan Haile, N.S., 2001. Middle Jurassic radiolarian chert, Indarung, Padang District, and its implications for the tectonic evolution of western Sumatera, Indonesia. Journal of Asian Earth Science, 19, hal. 31-44.

Prabowo, H., 2007. Pengaruh Intrusi Basalt terhadap Kualitas Batugamping Bukit Karang Putih, PT Semen Padang. Tesis Program Studi Rekayasa Tambang ITB: Bandung. Tidak dipublikasikan. 